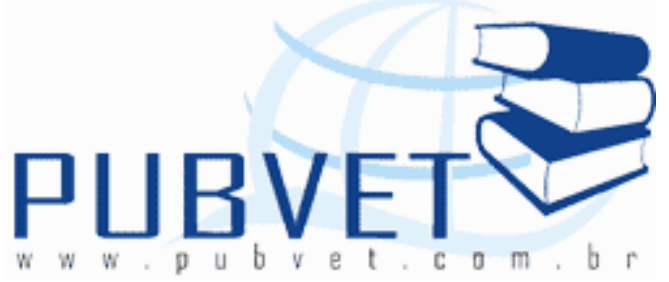

PUBVET, Publicações em Medicina Veterinária e Zootecnia.

\title{
Utilização de própolis (aditivo promotor de crescimento natural) na nutrição de ruminantes ${ }^{1}$
}

Luiz Juliano Valério Geron²; Gabriela Paes da Silva3; Raquel Joana TrautmannMachado ${ }^{4}$; Dilma Alves da Silva ${ }^{4}$; Osvaldo Martins de Souza ${ }^{4}$; Renato Lima Cristo $^{5}$; Maria Isabel Leite da Silva ${ }^{5}$; Edimar Barbosa de Oliveira ${ }^{5}$

${ }^{1}$ Parte do trabalho de conclusão de curso do segundo autor;

2 Professor Doutor da Universidade do Estado de Mato Grosso - UNEMAT, Ljgeron@unemat.br

${ }^{3}$ Zootecnista formada pela Universidade do Estado de Mato Grosso - UNEMAT, gabriela_zootecnista@hotmail.com

${ }^{4}$ Professores Mestres da Universidade do Estado de Mato Grosso - UNEMAT, Raquel_trautmann@hotmail.com

${ }^{5}$ Bolsistas de iniciação cientifica (IC) da Universidade do Estado de Mato Grosso - UNEMAT, renatto-lima_@hotmail.com

\section{Resumo}

Este trabalho é uma revisão bibliográfica que trata sobre a utilização da própolis na nutrição de ruminantes, a qual tem apresentado grande avanço científico sobre a quantidade e forma a ser fornecida para os animais de produção com a finalidade de aumentar a produtividade animal. Desta maneira, esta revisão poderá disponibilizar aos nutricionistas o conhecimento técnico e as informações necessárias para um melhor balanceamento de dietas 
equilibradas com a utilização de aditivos naturais (própolis), buscando a maximização da produção animal. A própolis é uma substância resinosa, coletada por abelhas, nas partes da planta, tal como, o broto, botões florais e exsudatos resinosos. A sua composição química é bastante complexa e variada, estando intimamente relacionada com a ecologia da flora de cada região. Atualmente a própolis, vêm sendo utilizada como uma alternativa na nutrição dos ruminantes, com o objetivo de manter o equilíbrio benéfico da microbiota intestinal, especialmente em animais jovens ou em iminente condição de estresse. Serão abordadas aqui desde um breve histórico da própolis (aditivo natural), suas características e propriedades, bem como comparação entre o extrato de própolis e os ionóforos, prebióticos, probióticos e leveduras.

Palavras-chave: aditivos, microrganismos, prebióticos, probióticos

\section{Use of propolis (additive growth promoter) in ruminant nutrition}

\section{Abstract}

This paper is a literature review that deals with the use of propolis in ruminant nutrition, which has shown great scientific advances on the amount and form to be provided to farm animals in order to increase animal productivity. Thus, this review may make available to nutritionists technical knowledge and information needed to a balancing better balanced diets with the use of natural additives (propolis), seeking to maximize animal production. Propolis is a resinous substance, collected by bees, in plant parts, such as the bud, flower buds and resinous exudates. Its chemical composition is quite complex and varied, and is closely related to the ecology of the flora of each region. Currently the propolis, have been used as an alternative in the nutrition of ruminants, with the goal of maintaining the balance beneficial of intestinal microbiota, especially in young animals or in imminent stress condition. Will be addressed here since a brief history of propolis (natural additive), its 
characteristics and properties as well as comparison of propolis extract and ionophores, prebiotics, probiotics and yeast.

Keywords: additives, microorganisms, prebiotics, probiotics

\section{INTRODUÇÃO}

A própolis tem sido estudada em vários países, e tem demonstrado importantes propriedades, como atividades antimicrobianas, cicratizantes, antinflamatórias, e terapêuticas (OLIVEIRA et al., 2006).

De acordo com Farnesi (2007), no que se refere a composição química da própolis, denominada como exata ou pura, a própolis em sua maioria é composta por $50 \%$ de resina e bálsamo vegetal, $30 \%$ de cera, $10 \%$ de óleos essenciais e aromáticos, $5 \%$ de pólen e $5 \%$ de outras substâncias variadas, incluindo os restos orgânicos. A própolis é atualmente considerada entre pesquisadores, como uma das misturas mais heterogêneas encontradas em fontes naturais; sendo que atualmente mais de 300 constituintes já foram identificados e caracterizados em diferentes amostras de própolis.

Atualmente, no Brasil são descritas propriedades biológicas e composição química distinta para diferentes amostras de própolis coletadas em diferentes partes do país. Devido a grande biodiversidade brasileira e pela habilidade bioquímica das abelhas em alterar a composição nativa ou adicionar componentes próprios à própolis. No Brasil, a coleta de própolis se dá durante todo o ano, favorecendo assim essa variação sazonal na sua composição, em que a diminuição em alguns componentes biologicamente ativos como os fenólicos são acompanhados pelo aumento de outros, como por exemplo, os ácidos diterpênicos (RIGHI, 2008).

Segundo Stradiotti (2004), os ionóforos no rúmen se caracterizam por promover mudanças na população microbiana, selecionando as bactérias gram-negativas, produtoras de ácido succínico ou que fermentam ácido láctico e inibem as gram-positivas, produtoras de ácidos acético, butírico e láctico e hidrogênio $\left(\mathrm{H}_{2}\right)$. Sendo que as bactérias ruminal gram-positivas são mais 
resistentes aos ionóforos que as gram-negativas, devido o seu envoltório celular ser constituído por uma parede celular e membrana externa de proteção constituída por proteínas, lipoproteínas e lipopolissacarideos, a qual contem canais de proteínas, de tamanho de, 600 Dalton. Mas, a maior parte dos ionóforos é maior que 600 Dalton e, consequentemente, não passam através dos canais, tornando as células impermeáveis aos ionóforos.

Desde janeiro de 2006, os ionóforos estão proibidos de serem utilizados nos países europeus. A justificativa para a proibição do uso de ionóforos está relacionada a uma eventual resistência de bactérias aos ionóforos, onde a mesma é vista como prejudicial à saúde humana. Porém temos os que defendem a liberação do uso dos ionóforos, pelo fato de não haver a comprovação de que esse pode causar resistência às bactérias e, principalmente, pelo alto benefício-custo desses aditivos, bem como o mesmo pode contribuir com a redução do efeito estufa (PRADO, 2010).

Os probióticos se referem a uma nova geração de aditivos alimentares, sendo em grande parte compostos por leveduras ou lactobacillus. As leveduras são reconhecidas como fonte rica em vitaminas, aminoácidos, proteínas e outros co-fatores importantes que as tornam fundamentais como auxiliares na digestão e bem como por atuar como uma fonte básica de nutrientes (BERCHIELLI, 2006).

O ministério da Agricultura define 0 aditivo como substância intencionalmente adicionada ao alimento com a finalidade de conservar, intensificar ou modificar suas propriedades, desde que não prejudique seu valor nutritivo. Em dietas de bovinos confinados a utilização de aditivos alimentares tem como objetivo principal a melhoria da conversão alimentar e/ou ganho de peso, embora benefícios secundários possam ocorrer como a melhoria na sanidade geral do animal. Entre os aditivos utilizados nas dietas de ruminantes existem antibióticos, aditivos microbianos (bactérias, fungos, leveduras), enzimas fibrolíticas, ácidos graxos, lecitina, ácidos orgânicos, extratos naturais de plantas (taninos saponinas, óleos essenciais), e outros extratos (própolis) (NICODEMO, 2001). 
Assim, surge à questão, qual a importância de se saber cada vez mais sobre os microrganismos naturais e da própolis com relação a atividade microbiana no rúmen de animais ruminantes (bovino, ovinos, caprinos e etc). Está revisão aborda a utilização da própolis como aditivo natural modificador da fermentação ruminal na alimentação dos animais ruminantes, principalmente pela capacidade de transformação dos carboidratos estruturais, principais constituintes das gramíneas, em ácidos graxos voláteis, e seus efeitos sobre a eficiência de produção (ganho médio diário, conversão alimentar, eficiência alimentar) e sua comparação aos aditivos convencionais.

\section{REVISÃO BIBLIOGRÁFICA}

\subsection{Contextualização da Própolis}

A própolis é um dos muitos produtos naturais que vem sendo utilizada pela população durante gerações. Os egípcios conheciam as propriedades antiputrefativas da própolis e as utilizavam para ser feito o embalsamento de cadáveres. Além disso, a própolis teve reconhecimento também por suas propriedades medicinais através de médicos gregos e romanos como Aristóteles, Dioscorides, Plínio e Galeno por suas propriedades medicinais (RIVERA, 2011).

Segundo Adelmann (2005), os sacerdotes do antigo Egito utilizavam a própolis como substância medicinal, bem como parte integrante dos ungüentos e cremes de embalsamar. Posteriormente, passou a ser utilizada pelos persas, romanos e incas no tratamento de infecções. Foram dos gregos, que se originou o termo própolis onde pro significa "em defesa de" e polis "cidade", em suma sua definição significa, em defesa da cidade ou da colméia.

Para Casimiro (2008), tal definição está relacionada ao fato da própolis ser uma resina coletada pelas abelhas da espécie Apis mellifera, sendo coletada de diversas partes das plantas, como botões florais e brotos, a mesma apresenta uma coloração variável entre o verde-amarelado ao preto e 
um odor característico, sendo solúvel em benzeno, éter, álcool, acetona e outros.

De acordo com Oliveira et al. (2005), vários fatores têm influência direta na composição química da própolis, como a variabilidade genética das rainhas e a ecologia vegetal da região. Mediante vários estudos, descobriu-se que as abelhas fazem utilização da própolis para assegurar as condições ambientais necessárias à sobrevivência do enxame dentro da colméia.

Nas colméias, as abelhas se utilizam dessa substância para proteção contra insetos e microrganismos, empregando-as em camadas finas nas paredes internas das colméias, contribuindo para fechar possíveis buracos e rachaduras, com isso repara e fortalece os favos de mel, e protege a entrada da colméia, proporcionando ambientes assépticos para a postura da abelha rainha e para mumificação de insetos invasores. É comum encontrar na colméia pequenos animais ou parte deles envoltos em própolis, em perfeito estado de conservação, já que à própolis também atribui-se ação antimicrobiana, o que impede a decomposição do cadáver (FARNESI, 2007).

Como podemos observar a própolis é conhecida e utilizada pelo homem desde os tempos mais remotos. O reconhecimento das propriedades e utilização da própolis era descrito pelos gregos, assírios, romanos, incas e egípcios. Sendo que no primeiro texto médico conhecido como "Livro de produção de medicamentos para todas as partes do corpo humano", descrito em papiro de Ebers e escrito há aproximadamente 1.700 a.C., faz-se uma descrição da mesma como um produto de ação medicinal (ALDEMANN, 2005).

De acordo com Rivera (2011), o interesse pela própolis no Brasil se deu somente na década de 80, através do trabalho pioneiro de Ernesto Ulrich Breyer, que demonstrou as propriedades terapêuticas que a própolis possuía e sua utilização como antibiótico natural. Com relação a primeira publicação sobre a própolis, ocorreu no ano de 1.984 e se referiu a um estudo que comparou o efeito de antibióticos e da própolis na inibição de Staphylococcus aureus. 
Foram encontrados registros em receituários chineses antigos como medicamento ativo contra moléstias coronárias e hipertensão (atribuindo a mesma uma ação hipolipêmica) e disfunções hematológicas (ADELMANN, 2005). Na antiga União Soviética, a própolis foi reconhecida e mereceu destaque por suas funções tanto na medicina humana como na área da zootecnia (veterinária), com aplicações inclusive no tratamento da tuberculose, observando-se a regressão dos problemas pulmonares e recuperação do apetite.

A própolis brasileira analisada em diversos estudos apresentou mais atividade do que vários outros antibióticos que foram testados. Com relação a sua utilização pelo ser humano, a própolis tem se destacado por sua atividade antimicrobiana, antiinflamatória, cicatrizante e anestésica e suas propriedades terapêuticas. Os denominados efeitos antimicrobianos e antinflamatórios da própolis têm sido atribuídos aos flavonóides, ésteres e derivados do ácido cafeíco (PRADO, 2008).

No decorrer dos anos, através de estudos e pesquisas em vários países, tem se descoberto outras atribuições para a própolis, que vem cada vez mais se destacando não só pelas suas propriedades terapêuticas, mas também pela sua utilização na indústria alimentícia, como alimentos funcionais para animais ruminantes. Foi constatado que a própolis, apresenta uma grande variedade no rendimento de sólidos totais, flavonóides totais, fenólicos totais, atividade antimicrobiana, atividade antioxidante, assim como no perfil cromatográfico, eletroforético e espectrofotométrico entre as diferentes amostras de própolis, mesmo fixando a variedade da abelha coletora, devido às diferenças na origem geográfica e consequentemente na composição das mesmas (PARK, 2000).

Segundo pesquisas realizadas por Valero (2010), as amostras de própolis que possuem maiores teores de flavonóides e fenólicos totais, nem sempre vão apresentar maiores atividades biológicas, ou seja, funções antimicrobianas e antioxidantes, onde se pode comprovar que não se refere só à quantidade destes compostos presentes na própolis, mas fundamentalmente a qualidade 
dos mesmos exerce uma grande influência nas atividades biológicas destas amostras.

Segundo Casimiro (2008), as propriedades biológicas da própolis estão diretamente ligadas a sua composição química, e esta provavelmente pode ser um dos maiores problemas para o uso da própolis em fitoterapia, pelo fato de que a sua composição química varia conforme a flora da região (brotos, cascas, galhos, exsudatos e botões florais) bem como pela época da colheita, a técnica empregada na colheita, a espécie da abelha no caso da brasileira, também o grau de "africanização" da Apis melífera pode influenciar a sua composição, conjunto este que exerce uma enorme importância nas propriedades físicas, químicas e biológicas da própolis.

\subsection{Atividades Antibacteriana e Antifúngica da Própolis}

Para Adelmann (2005), nesses últimos anos a literatura científica vem relatando as propriedades farmacológicas da própolis, dentre elas sua atividade bacteriostática e bactericida, fungistática e fungicida, virustática e virucida, antioxidante e outras. Todas estas atividades biológicas associadas a tendência de utilização de produtos naturais tem proporcionado grande resultado no mercado farmacêutico, um grande aumento na procura da própolis e produtos contendo própolis, como extratos, cápsulas, comprimidos, nebulizações ou pós.

De acordo com Pinheiro (2009), durante os últimos anos tem sido relatado em experimentos in vitro que a atividade antimicrobiana da própolis é devido aos flavonóides, aos ácidos aromáticos e ésteres presentes na resina natural.

Os flavonóides conhecidos por galangina, pinocembrina e pinostrombina são tidos como os mais efetivos contra bactérias, e já os ácidos ferúlicos e cafeíco contribuem, porem em menor intensidade para a ação bactericida da própolis. O mecanismo de atividade antimicrobiana é complexo e provavelmente baseado na inibição da RNA-polimerase bacteriana podendo 
decorrer de um efeito sinergístico entre flavonóides, hidroxiácidos e sesquiterpenos (GOULART, 1990).

Segundo Langoni et al. (1998), em estudo in vitro com extrato de própolis na concentração de $5 \%$ observaram inibição no crescimento de microrganismos como descritos na Tabela 1.

Tabela 1 - Frequência de bactérias analisadas em testes in vitro com extrato de própolis

\begin{tabular}{lc}
\hline Bactérias & Freqüência ( \%) \\
\hline Staphylococcus aureus & $100 \%$ \\
Prototheca zopfii, & $100 \%$ \\
Corynebacterium bovis & $100 \%$ \\
Rhodococcus equi & $100 \%$ \\
Geothricum candidum & $100 \%$ \\
Escherichia coli & $91 \%$ \\
Streptococcus agalactiae & $90 \%$ \\
Klebsiella pneumoniae & $87,5 \%$ \\
Pseudômonas aeruginosa & $85,7 \%$ \\
Salmonella SP & $81,3 \%$
\end{tabular}

Adaptado de Langoni et al (1998).

No tratamento de vacas com mastite aguda, segundo Loureiro (2007), a utilização da própolis obteve como resultado uma recuperação de $86,6 \%$ dos animais, com $100 \%$ de recuperação quando causados por Candida albicans (levedura); $85 \%$ por E. coli; $91 \%$ por Staphylococcus e $84,3 \%$ por Streptococcus, desta maneira os autor concluiu que a própolis é um aditivo medicamentoso efetivo na terapia da mastite causada por microrganismos resistentes a antibióticos.

Para Aldemann (2005), em pesquisas mais especificas, verificou uma ação marcante da própolis sobre bactérias gram-positivas e uma atividade limitada contra as gram-negativas. Este mesmo pesquisador trabalhou em laboratório com diferentes agentes causadores de mastite bovina e observou que os extratos etanólicos e metanólicos da própolis inibiram o crescimento das amostras de bactérias gram-positivas, Staphylococcus aureus, 
Staphylococcus sp. Coagulase negativos e Streptococcus agalactiae, porém não revelou capacidade em inibir o crescimento das amostras gram-negativas.

Cabral (2008) em experimento avaliando a atividade antimicrobiana in vitro do extrato etanólico de própolis (EEP) em frações hexânica e clorifórmica utilizou como controle positivo a clorexidina $0,12 \%(\mathrm{~m} / \mathrm{v})$ um antimicrobiano que tem elevado poder de ação, e como controle negativo o etanol $80 \%(\mathrm{v} / \mathrm{v})$ através do teste de difusão em águar, observou a atividade antimicrobiana da própolis vermelha. Os valores da média dessas zonas com atividade antimicrobiana nas placas de petri em milímetros podem ser observados na Tabela 2. Verificou-se que a atividade antimicrobiana ficou concentrada na fração clorifórmica, e as zonas de inibição também foram maiores até mesmo que o EEP.

Tabela 2: Medias de zonas de inibição de crescimento $(\mathrm{mm})$ Staphylococcus aureus, Streptococcus mutans Ingbritti e Actynomices naes/undii em frente ao EEP-Extrato etanólico de própolis, fração-hexânica, fração-clorofórmica

\begin{tabular}{lccc}
\hline Tratamento & S.aureus & S, mutans & A, naes/undii \\
\hline EEP (Extrato etanólico de própolis) & $4,9+0,5$ & $2,4+0,1$ & $4,6+0,1$ \\
Fração Hexânica & $2,2+0,7$ & $\mathrm{Nd}$ & $1,9+0,1$ \\
Fração Clorofórmica & $5,7+0,4$ & $3,7+0,2$ & $5,5+0,5$ \\
Clorexidina0,12\%(controle positivo) & $3,4+0,4$ & $4,8+0,2$ & $6,1+0,3$ \\
Etanol 80\%(controle negativo) & $\mathrm{Nd}$ & $\mathrm{Nd}$ & $\mathrm{Nd}$ \\
\hline
\end{tabular}

*nd=valor não detectado. Adaptado de Cabral (2008).

Durante a avaliação realizada por Loureiro (2007), sobre a utilização de extrato de própolis a $11 \%$ incorporado ao concentrado nas doses de $15 \mathrm{mg} \mathrm{e}$ $30 \mathrm{mg}$, para cordeiros foi observado que o tratamento 2 com adição de $30 \mathrm{mg}$ de extrato de própolis, teve um melhor efeito em reduzir o número de ovos por grama de fezes quando comparado com o tratamento 1 , com $15 \mathrm{mg}$ de própolis e o tratamento controle como demostrado na Tabela 3. 
Tabela 3: Teor de flavonóides totais, consumo de matéria (CMS), valores médios das contagens de ovos grama de fezes (OPG) de cordeiros alimentados com extrato de própolis na ração e os respectivos coeficientes de variação

\begin{tabular}{lccc}
\hline Ração & $\begin{array}{c}\text { Teor de Flavonóides } \\
(\mathrm{mg} / \mathrm{mL})\end{array}$ & $\begin{array}{c}\mathrm{CMS} \\
(\mathrm{K}=\mathrm{kg} / \mathrm{dia})\end{array}$ & OPG \\
\hline $\mathrm{T}^{0}$ & 0,00 & 0,365 & 3,53 \\
$\mathrm{~T}^{1}$ & 90,45 & 0,285 & 3,09 \\
$\mathrm{~T}^{2}$ & 180,90 & 0,230 & 3,06 \\
\hline $\mathrm{CV}^{2}(\%)$ & - & 16,75 & 14,23 \\
\hline $\mathrm{T}^{0}=$ controle, sem adição de extrato de própolis; $\mathrm{T}^{1}=$ adição de $15 \mathrm{mg}$ de extrato de própolis/kg \\
de peso corporal; $\mathrm{T}^{2}=$ adição de $30 \mathrm{mg}$ de extrato de própolis $/ \mathrm{kg}$ de peso de \\
corporal. ${ }^{2} \mathrm{CV}=$ coeficiente de variação. Adaptado de Loureiro (2007).
\end{tabular}

Segundo Park (2000), a própolis possui atividade antimicrobiana contra Staphylococcus aureus, porém pode não atuar de forma eficaz sobre o Streptococcus mutans. O efeito terapêutico da própolis apresenta variações, de acordo com a qualidade da mesma, não havendo, portanto, um método padrão para avaliar sua qualidade, que na maioria das vezes leva em consideração os teores de flavonóides e quercetina.

Pesquisa realizada por Loureiro (2007), no qual administrou própolis para coelhos por via oral, como agente anticoccidiano, (solução alcoólica de 95\%) verificou uma redução na excreção de oocistos de Eimeria sp. Ao realizar uma comparação entre coelhos infectados com Eimeria magna e Eimeria perforans, tratados com solução hidroalcoólica de própolis e sulfa, chegou a identificar que os efeitos anticoccidianos da própolis foram superiores aos tratamentos com sulfa, sugerindo uma opção do uso da própolis no tratamento da coccidiose.

A utilização de extratos obtidos através de técnicas de extração em etanol $(99,5 \%)$ e extração em etanol hidratado (70\%) memostraram redução na atividade de produção de amônia pela microbiota ruminal, sendo que a extração com 70\% de etanol foi mais eficiente (STRADIOTTI JR et al., 2001).

Oliveira et al. (2004) estudaram a atuação do extrato de própolis e da monensina na produção de amônia e degradabilidade in vitro de diferentes 
fontes de proteína os quais observaram que o extrato de própolis e a monensina apresentaram a mesma eficácia na inibição da produção de amônia em duas fontes de nitrogênio (tripticase e farelo de soja).

A utilização da própolis foi mais eficiente que a monensina em manter maiores concentrações de proteína solúvel no início das incubações, pela redução da atividade de deaminação, em bovinos fistulados, segundo Oliveira et al. (2006). Este mesmos autores observaram que embora a própolis não tenha alterado a proporcionalidade entre os ácidos graxos voláteis (AGVs), ela aumentou a concentração total dos mesmos, o que, em linhas gerais, confere aos ruminantes maior possibilidade de se manterem e produzirem a partir de uma mesma dieta.

Revisão realizada por Prado (2005) demonstrou que alguns pesquisadores analisaram a digestibilidade in vitro da matéria seca (DIVMS) de dietas contendo $50 \%$ de volumoso e $50 \%$ de concentrado e $100 \%$ de volumoso, submetidas a soluções com diferentes concentrações e diluentes de própolis e compararam com os resultados proporcionados pela monensina. As duas diferentes dietas com a inclusão das diluições de própolis apresentaram resultados superiores $(p<0,05)$ a monensina. A própolis propiciou uma digestibilidade in vitro da matéria seca (DIVMS) para a dieta com $100 \%$ de volumoso de $49,9 \%$ contra $39,09 \%$ da monensina, para a dieta com $50 \%$ volumoso e $50 \%$ concentrado a própolis propiciou uma digestibilidade DIVMS de $57,37 \%$ contra $54 \%$ da monensina.

A própolis apresentou-se mais eficiente que a monensina em reduzir a produção de amônia e culturas de microrganismos ruminais em meio contendo caseína hidrolisada. A produção de amônia normalizou assim que o ionóforo "monensina" foi removido do meio de cultura, provavelmente em razão do restabelecimento da população de bactérias produtoras de amônia, comprovando a ação bacteriostática desse antibiótico. Entretanto, no tratamento com própolis, a produção de amônia manteve-se em níveis baixos mesmo quando removida do meio de cultura, indicando uma ação bactericida (VALERO, 2010). 
Segundo Stradiotti Jr. et al. (2004), o que tem atraído mais a atenção dos pesquisadores tem sido os flavonóides presentes na própolis da região de Maringá, Estado do Paraná, o qual variou de 2,05\% a 5,52\% nos períodos de inverno a verão, respectivamente. As substâncias que predominam na composição da própolis, embora quimicamente distintas, nas própolis de uma e outra região, são sempre de natureza fenólica e com propriedades antissépticas. Os flavonóides e os ácidos fenólicos são atribuídos as propriedades antibacterianas, antiviral, antioxidante, antifúngica, antiinflamatória, antiprotozoário, entre outras. Esse potencial biológico se deve a um sinergismo que ocorre entre os muitos constituintes da própolis.

A atividade biológica da própolis está sendo comprovada cientificamente, no entanto, sua utilização na área veterinária e zootécnica tem sido limitada pela grande variabilidade nas amostras, pelas fontes vegetais, às diferentes técnicas de extração, aos diferentes solventes e às diferentes concentrações utilizadas, bem como às diferentes técnicas para determinar sua composição química, tanto em termos da qualificação, quanto da quantificação de seus componentes (PRADO, 2005).

A própolis oriunda do Rio Grande do Sul apresentou maiores concentrações de pinocembrina, crisina, acacetina e galangina (PEREIRA et al., 2002) em relação a própolis do Paraná e São Paulo.

Segundo Oliveira et al. (2006), a própolis apresenta-se mais eficiente que a monensina por apresentar a ação de reduzir a produção de amônia de culturas de microrganismos ruminais em ambiente contendo caseína hidrolisada. Diante destas respostas, possivelmente, a própolis possa ser usada para melhorar o desempenho animal, na manipulação dos microrganismos, uma vez que demonstrou o poder inibidor do crescimento de algumas bactérias gram-positivas, as quais são responsáveis pelos processos de fermentação ruminal consideradas ineficientes ou mesmo prejudiciais.

Os efeitos da própolis dependem da sua composição, e consequentemente, da região de coleta das amostras de própolis. Na área veterinária, a própolis foi testada em casos de pododermite necrótica em 
ovinos; na coccidiose em coelhos, na pneumonia em bezerros; em enterites catarral, fibrinosa e hemorrágica, em bezerros; nos vírus da enfermidade Aujeszky e na cepa La Sota dos vírus da enfermidade New Castle, em animais de laboratório e embriões de frango; entre outros, sendo em todos esses trabalhos confirmada a sua ação terapêutica (ADELMANN, 2005).

\subsection{Uso do Extrato de Propólis Sobre a Digestão Ruminal dos Alimentos}

O avanço científico sobre as exigências dos animais e dos valores nutritivos dos alimentos disponibilizou aos nutricionistas o conhecimento técnico e as informações necessárias para o balanceamento de dietas precisas de acordo com cada categoria e nível de produção desejado. Neste contexto, a descoberta de compostos que controlam o metabolismo aumentando a eficiência de utilização de alimentos e proporcionando uma maior produção animal, deu origem a uma nova classe de substâncias denominadas de aditivos alimentares (SILVA e LEÃO, 1979).

Segundo Silva e Leão (1979), o rúmen é o maior dos compartimentos do sistema digestivo de animais ruminantes, que proporciona condições para ser povoado por milhões de microrganismos (bactérias, fungos, leveduras e protozoários). A relação entre microrganismo e o animal hospedeiro é simbiótica, e o animal proporciona o controle do ambiente (temperatura $39^{\circ} \mathrm{C}$, $\mathrm{pH}$ entre 5,5-7,0, anaerobiose e substrato constante) e os microrganismos degradam carboidratos estruturais e não-estruturais até ácidos graxos voláteis (acetato, propionato e butirato) e a proteína até amônia, os quais serão utilizados pelo ruminante em várias rotas metabólicas, ou utilizados para multiplicação de massa microbiana que passará do rúmen para ser absorvida no intestino como principal suprimento de proteína para o animal hospedeiro.

Os microrganismos ruminal são de grande valor para os animais ruminantes, pelo fato do mesmo transformar os carboidratos estruturais, principais constituintes das gramíneas, em ácidos graxos voláteis, que são 
fontes de energia disponíveis para absorção do alimento; bem como contribuem com suprimento de proteínas e vitaminas aos animais, após a digestão e absorção das mesmas no intestino delgado (OLIVEIRA et al., 2006).

Para Prado (2008), os probióticos utilizados na alimentação dos ruminantes são alternativas para a substituição dos aditivos químicos, visto que os mesmos são definidos como suplementos alimentares formados de culturas puras ou composta de microrganismos vivos, com a função de se instalar e proliferar no trato gastrintestinal do animal trazendo benefícios à saúde do mesmo.

Algumas cepas de leveduras dentro do rúmen possuem características desejáveis ao animal, visto que as inserções destas leveduras vivas na dieta do animal aumentam a população bacteriana ruminal, que possuem a capacidade de alterar a atividade metabólica específica do rúmen, favorecendo o aumento da proteína microbiana, atuando na digestão da celulose e beneficiando uma maior utilização do ácido lático (QUEIROZ, 2004).

Dentre os promotores de crescimento temos o Procreatin-7 que pode ser definido como um composto de leveduras vivas da cepa de Saccharomyces cerevisiae que tem como função atuar neutralizando as flutuações de $\mathrm{pH}$, mantendo o mesmo na zona equilibrada e eliminando o oxigênio presente no rúmen o que vai potencializar de modo benéfico o funcionamento da flora ruminal. Consequentemente vai ocorrer uma melhora na digestão da fibra dos alimentos; uma maior produção de proteína microbiana maior otimização do aproveitamento da forragem e, por fim um maior ganho de peso e fertilidade dos animais (RÍSPOLI et al., 2009).

De acordo com Aguiar (2009), a produção de metano pelas bactérias pode corresponder a uma perda energética de aproximadamente $13 \%$ em relação à energia do alimento ingerido. Essa diminuição favorece na redução da poluição ambiental, visto que atualmente, o gás metano tem sido um dos principais responsáveis pela destruição da camada de ozônio.

O gás metano é eliminado pelos ruminantes, através da eructação, causando o efeito estufa e a destruição da camada de ozônio da atmosfera. Ou 
seja, pode-se considerar que um bovino adulto chega a produzir mais de 400 litros de gás por dia (metano + dióxido de carbono), sendo este liberado no meio ambiente, principalmente por eructação torna-se uma grande ameaça a vida humana (STRADIOTTI JR et al., 2004).

De acordo com Valadares Filho, (2006) algumas bactérias celulolíticas apresentam como principal fonte de nitrogênio (N) a amônia, sendo que esta é resultante de um processo fermentativo da proteína. Porém, quando a concentração de amônia está em excesso no fluído ruminal, por outro lado, essa não é utilizada eficientemente para a síntese microbiana o que resultará no aumento da excreção de nitrogênio, e consequentemente aumentando o custo energético de produção de uréia. O excesso de amônia será excretado através da urina e dessa forma podendo contaminar solos e cursos d'água.

Segundo a literatura, os denominados intermediários da produção de amônia são os aminoácidos e peptídeos, que são provenientes da quebra da proteína solúvel do alimento através de enzimas microbianas ruminais, sendo estes incorporados à proteína microbiana ou deaminados. Mas quando ocorre uma quebra excessiva de peptídeos, os mesmos deixam de ser assimilados totalmente no organismo animal, ocorrendo uma perda desses na forma de amônia. Atualmente se descobriu uma maneira de se reduzir essa perda de nitrogênio pelo animal, dentre eles, através da administração dos inibidores bacterianos, como monensina e própolis (MARTINS et al., 2006).

Quando se tem uma quebra excessiva de peptídeos, eles não são assimilados totalmente, o que ocorre uma perda desses na forma de amônia. Uma forma de reduzir essa perda de nitrogênio pelo animal seria através da administração dos inibidores bacterianos, como a própolis e a monensina (Stradiotti Jr. et al., 2001).

De acordo Stradiotii Jr et al. (2004) o uso do extrato de própolis reduziu o volume total e a produção final total e a produção final de gases para carboidratos fibrosos quando comparado com o tratamento controle (solução alcoólica a 70\%) e verificou-se que a taxa de ingestão específica para 
carboidratos fibrosos e carboidratos não-fibrosos foi superior quando utilizado o extrato de própolis como pode ser visto na Tabela 4.

Tabela 4: Produção de gases (volume final total-vf e volume final para carboidratos fibrosos - Vfcf) e taxa de ingestão específica de carboidratos fibrosos-kcf e não fibrosos-kcnf

\begin{tabular}{lcccc}
\hline Tratamento & Vf & Vfcf & Kcf & Kcnf \\
\hline Extrato de própolis* & 30,62 & 19,67 & 0,0235 & 0,1692 \\
Solução alcoólica 70\% & 33,75 & 22,06 & 0,0195 & 0,1179 \\
\hline *Extrato de própolis = Solução estoque & $(30 \mathrm{gm}$ de própolis bruta em $100 \mathrm{ml}$ alcólica a $70 \%$ \\
em água) diluída pela metade com a mesma solução. Adaptado de Stradiotti Jr (2004).
\end{tabular}

\subsection{Uso da Própolis na Produção de Leite e na Produção de Carne}

No Brasil, a produção de leite e da carne tem se revelado uma atividade cada vez mais competitiva. Portanto, é importante quantificar e qualificar os fatores que podem favorecer a produção de ambos, buscando ganhos efetivos na quantidade e qualidade, tanto do leite quanto da carne bovina, visando suprir a demanda nacional e favorecendo a exportação dos produtos (GONSALVES e PEDREIRA, 2010).

Segundo Aguiar (2009), o uso de aditivos naturais na dieta alimentar dos ruminantes tem como função antibiótica, ajudar a evitar a probabilidade de doença e favorecer o crescimento, a eficiência alimentar e consequentemente a produção de leite e a qualidade da carne do animal. Porém nos casos em que há ausência de bactérias gastrintestinais, devido à presença de antibióticos na dieta, o processo do recrutamento de células imunes para o intestino fica comprometido, ou seja, ficam baixas e devido a esse fato o desempenho animal não é favorável, caso não ocorra o equilíbrio da microbiota intestinal, e muitas vezes esses patógenos no intestino podem causar lesões nos vilos, resultando em infecção intestinal, e com isso comprometer a digestibilidade da ração e ocasionalmente o surgimento de doenças. 
De acordo com Freitas et al. (2009), vacas leiteiras alimentadas com extrato etanólico de própolis indicou influência com relação a produção de leite, como pode ser visto na Tabela 5, enquanto que a contagem de células somáticas (CCS) não foram afetadas.

Tabela 5: Médias de produção de leite $(\mathrm{kg})$, produção de leite corrigida para $4 \%$ (PC 4\%) e contagem de células somáticas (CCS x1000), para dieta controle e com adição de extrato etanólico de própolis (EEP)

\begin{tabular}{lllllll}
\hline Tratamento & $\begin{array}{l}\text { Produção } \\
\text { media }(\mathrm{kg})\end{array}$ & $\begin{array}{l}\text { Erro } \\
\text { padrão }\end{array}$ & $\begin{array}{l}\text { PC4\% } \\
(\mathrm{kg})\end{array}$ & $\begin{array}{l}\text { Erro } \\
\text { padrão }\end{array}$ & CCS $(\times 1000)$ & $\begin{array}{l}\text { Erro } \\
\text { padrão }\end{array}$ \\
\hline Controle & 22,63 & 1,29 & 19,49 & 1,21 & 766,7 & 160,03 \\
EEP & 25,92 & 0,91 & 22,20 & 0,85 & 736,7 & 112,18 \\
\hline
\end{tabular}

Adaptada de Freitas et al. (2009).

Estudo comparando a monensina (tratamento positivo) e o extrato de própolis conduzido por Prado (2008) demonstrou que a monensina inibe basicamente as bactérias gram-positivas, visto que a resistência ao ionóforo está relacionada à presença de uma camada de ordem lipopolissacarídica, externa à membrana celular, existentes em bactérias gram-negativas, porém a monensina não apresenta valor significativo na nutrição do animal ruminante, por ter pouco impacto na média de peso e ganho diário do animal, porém sua contribuição encontra-se na diminuição da ingestão de alimento e na taxa acetato/proprionato no fluido ruminal como demonstrado na Tabela 6.

Segundo Stradiotti Jr et al. (2004), a utilização do extrato de própolis proporcionou à produção de ácidos graxos voláteis, e ocorreu um aumento na produção de propionato, e consequentemente uma redução na relação entre acetato e o propionato no rúmen. Sendo que uma maior proporção de propionato é benéfica, pelo fato de disponibilizar no rúmen, menores quantidades de carbono e hidrogênio que seriam utilizados na produção do metano e essa redução na produção de metano é positiva e significa aumento na eficiência energética e melhor desempenho animal. 
Tabela 6: Valores médios de pH ruminal, nitrogênio amoniacal e produção de AGV para bovinos alimentados com dieta volumosa contendo ou não aditivos a base de própolis LLOS ${ }^{1}$ e monensina

\begin{tabular}{lccccc}
\hline Variáveis & \multicolumn{4}{c}{ Tratamentos } & \multirow{2}{*}{$\%$ CV } \\
\cline { 2 - 5 } & Testemunha & Monensina & LLOS1 & LLOSB3 \\
\hline $\mathrm{Ph}$ & 6,37 & 6,43 & 6,24 & 6,18 & 4,06 \\
$\mathrm{~N}-\mathrm{NH}^{3}(\mathrm{mg} / 100 \mathrm{ml})$ & 10,32 & 9,44 & 11,29 & 11,54 & 43,95 \\
AGV total $(\mu \mathrm{m} / \mathrm{ml})$ & 81,22 & 80,97 & 89,90 & 95,04 & 15,78 \\
Acetato $(\mu \mathrm{m} / \mathrm{ml})$ & 59,03 & 57,08 & 64,85 & 69,28 & 14,84 \\
Propionato $(\mu \mathrm{m} / \mathrm{ml})$ & 14,40 & 16,10 & 15,37 & 16,44 & 20,80 \\
Butirato $(\mu \mathrm{m} / \mathrm{ml})$ & 7,79 & 7,79 & 9,07 & 9,31 & 32,93 \\
Ace:Prop & 4,23 & 3,65 & 4,33 & 4,35 & 13,20 \\
\hline
\end{tabular}

LLOS: produto a base de extrato de própolis com extração em teores alcoólicos (1 e 3) e diferentes concentração de própolis (B e C),LLOSC1 e LLOSCB3. Adaptado de Prado (2008).

De acordo com Aguiar (2009), as dietas experimentais (Controle, LLOSC1 e LLOSC1+), tiveram influência no consumo na conversão da matéria seca e ganho médio diário como demonstrado na Tabela 7. Mas este autor verificou uma melhoria de $12 \%$ na conversão alimentar para os animais que receberam uma dosagem maior de própolis e de $5 \%$ aos que receberam a dieta controle. Como também verificado por Zawadzki et al. (2008), esse resultado parece indicar que em dosagens maiores dos produtos a base de própolis pode se tornar uma alternativa para melhorar a eficiência da dieta com $50 \%$ de concentrado em confinamento.

Tabela 7: Desempenho de bovinos mestiços não castrados alimentados com $50 \%$ de volumoso e $50 \%$ de concentrado sem (CON) e com adição de produtos a base de própolis em diferentes dosagens (LLOSC1 e LLOSC+), durante 84 dias de confinamento

\begin{tabular}{|c|c|c|c|c|c|c|}
\hline \multirow[t]{2}{*}{ Características } & \multicolumn{3}{|c|}{ Tratamentos } & \multirow[t]{2}{*}{ Médias } & \multirow{2}{*}{$\begin{array}{l}\text { Erro- } \\
\text { padrão }\end{array}$} & \multirow{2}{*}{$\begin{array}{l}\text { CV1 } \\
\%\end{array}$} \\
\hline & CON & LLOSC1 & LLOSC1+ & & & \\
\hline PVI,Kg & 353,63 & 352,00 & 352,44 & $352,69+27,89$ & 5,36 & 8,24 \\
\hline $\mathrm{PVF}, \mathrm{Kg}$ & 470,50 & 458,78 & 473,22 & $467,50+29,45$ & 5,66 & 6,41 \\
\hline $\mathrm{GMD}, \mathrm{Kg}$ & 1,81 & 1,62 & 1,84 & $1,76+0,34$ & 0.06 & 19,36 \\
\hline IMS, Kg/dia & 10,57 & 9,70 & 9,92 & $10,06+1,32$ & 0,25 & 13,15 \\
\hline IMS \%PV & 2,55 & 2,39 & 2,40 & $2,45+0,22$ & 0,04 & 8,90 \\
\hline CAMS $^{2}$ & 5,85 & 6,27 & 5,51 & $5,88+1,03$ & 0,20 & 17,5 \\
\hline
\end{tabular}

${ }^{1}$ Coeficiente de variação; ${ }^{2} \mathrm{Kg}$ MS/Kg. GMD. PVI: peso vivo inicial; PVF: peso vivo final; GMD: ganho médio diário; IMS: ingestão de matéria seca; CAMS: conversão alimentar da matéria seca. Adaptado de Aguiar (2009). 
A monensina atualmente é utilizada em dietas para animais que consomem grande quantidade de grãos, onde favorece uma pequena economia na hora da aquisição dos alimentos, para os grandes produtores de carne ou leite. A própolis, ou o extrato de própolis pode ser utilizado como aditivo modificador da fermentação ruminal na dieta de animais ruminantes (PRADO, 2008), uma vez que seleciona algumas cepas de bactérias.

Segundo Simioni (2011), em estudo com dietas sem e com produtos a base de extrato de propólis LLOS C1, em bovinos anelorados, em um período de confinamento de 84 dias, observou que o peso corporal final dos animais que receberam dieta com LLOS $\mathrm{C} 1++$ (duas doses inicial do LLOS C1) se mostrou maior que a dieta LLOS $\mathrm{C} 1+++$, mas se mostraram semelhantes aos animais que receberam a dieta controle. Para ganho de peso observou superioridade do LLOS $\mathrm{C} 1++$ em $42 \%$ comparado com a LLOS C1+++ e de $17 \%$ em relação a dieta controle para os 28 dias de confinamento, já no período total de 84 dias de confinamento constatou ainda a superioridade do LLOS C1 ++, mas com queda nessas diferenças de 26\% e 11\%. Para o ganho médio diário um maior valor para a dieta com LLOS $\mathrm{C} 1++$ em relação ao LLOS $\mathrm{C} 1+++$, como pode ser observado na Tabela 8.

Segundo Oliveira et al. (2007), o efeito da adição de própolis ao meio diluidor em diferentes concentrações $(0,25$ e 0,5\%) e sua influência nas características físicas do sêmen equino resfriado a $5^{\circ} \mathrm{C}$ indicou que a própolis não teve efeitos benéficos sobre as características físicas do sêmen equino resfriado a $5^{\circ} \mathrm{C}$.

A melhora na eficiência alimentar dos ruminantes pode ser atribuído a economia da energia advinda da incorporação dos carbonos e hidrogênios ao propionato, que seriam lançados no ar e até mesmo na atmosfera terrestre em forma de gás ( $\mathrm{CO}_{2}$ e metano), mediante a via eructação (AGUIAR, 2009). 
Tabela 8: Desempenho de bovinos confinados recebendo duas doses de produtos a base de própolis LLOSC1 como aditivo alimentar

\begin{tabular}{|c|c|c|c|c|}
\hline \multirow[b]{2}{*}{ Parâmetros } & \multicolumn{3}{|c|}{ Dietas } & \multirow[b]{2}{*}{ EPM } \\
\hline & Controle & LLOS C $1++$ & LLOS C $1+++$ & \\
\hline $\begin{array}{l}\text { Peso corporal inicial } \\
(\mathrm{Kg})\end{array}$ & 443,13 & 447,62 & 443,89 & 11,66 \\
\hline $\begin{array}{l}\text { Peso corporal final }(\mathrm{Kg}) \\
\text { Ganho Líquido }(\mathrm{Kg})\end{array}$ & 541,13 & 558,12 & 527,38 & 6,92 \\
\hline $0-28$ dias & 35,25 & 42,38 & 24,75 & 4,95 \\
\hline $0-56$ dias & 70,25 & 78,63 & 59,13 & 5,96 \\
\hline $\begin{array}{l}0-84 \text { dias } \\
\text { Ganho médio diário }(\mathrm{Kg}\end{array}$ & 98,00 & 110,50 & 81,25 & 61,81 \\
\hline $0-28$ dias & 1,259 & 1,513 & 0,084 & 0,177 \\
\hline 0-56 dias & 1,255 & 1,513 & 1,056 & 0,107 \\
\hline $0-84$ dias & 1,16 & 1,317 & 0,967 & 0,078 \\
\hline
\end{tabular}

A literatura diz que o propionato é o principal substrato precursor de glicose pela gliconeogênese no fígado e em níveis ou fases de produção em que a glicose oriunda da digestão do amido no intestino delgado não é suficiente $o$ bastante para atender às exigências de produção animal, como exemplo; vacas que durante o período de transição, ou seja, esses animais têm consumo reduzido nessa fase, proporciona uma maior produção de propionato ruminal (QUEIROZ, 2009).

Segundo Stradiotti Jr et al. (2010), mesmo que a própolis não tenha alterado a proporção entre os AGV'S por outro lado ela aumentou a concentração total dos mesmo, apesar de não significativo o extrato de própolis apresentou um aumento de $15 \%$ da relação acetato:propionato como pode ser visto na (Tabela 9), demostrando-se contrário ao observado em estudo que se utilizam modificadores da fermentação ruminal como exemplo os iónoforos e os lipídios.

Dentre os problemas que interferem na qualidade do leite do animal, temos uma infecção denominada mastite, sendo a mesma um processo inflamatório da glândula mamária acompanhado da redução de secreção de leite e mudança de permeabilidade da membrana que separa o leite do 
sangue. Essa enfermidade é a de maior prevalência na bovinocultura e esta diretamente vinculada às infecções microbianas. Há pouco tempo esses microrganismos envolvidos na gênese da mastite bovina foram agrupados de acordo com as fontes de infecção e vias de transmissão, e posteriormente classificados como contagiosos ou ambientais (SANTOS e SANTOS, 2001).

Tabela 9: Efeito do extrato de própolis sobre consumo de matéria seca (CMS), $\mathrm{pH}$, concentrações de amônia, proteína microbiana, ácidos graxos voláteis (AGV) em novilhos e atividade específica de produção de amônia (AEPA), por microrganismos ruminais

\begin{tabular}{lccc}
\hline Parâmetros & \multicolumn{2}{c}{ Tratamentos } & EPM \\
\cline { 2 - 3 } & Controle & Própolis & \\
\hline CMS (Kg/animal/dia) & 10,88 & 10,52 & 1,487 \\
pH ruminal & 6,36 & 6,52 & 0,105 \\
Amônia ruminal (Mm) & 4,89 & 5,56 & 0,343 \\
Proteína Microbiana(mg/L) & 2997,20 & 3076,20 & 194,029 \\
AEPA (nmol/mg PM/minuto) & 11,65 & 8,10 & 0,373 \\
\% Acetato & 72,40 & 74,90 & 1,28 \\
\% Propionato & 18,00 & 16,20 & 0.92 \\
\% Butirato & 9,52 & 8,80 & 0,59 \\
Relação Acetato:Propionato & 4,06 & 4,68 & 0,89 \\
AGV Total (Mm) & $60,8^{\mathrm{a}}$ & $94,8 \mathrm{~b}$ & 1,24 \\
\hline
\end{tabular}

Adaptado de Stradiotti Jr.et al. (2010).

Com relação ao perfil microbiológico dos rebanhos, inúmeras pesquisas têm apontado que o Staphylococcus sp tem sido considerado como o principal agente causador de mastite no Brasil. Essa presença do S. aureus e suas toxinas no leite usado por algumas indústrias e laticínios tem representado um grave problema de saúde pública (NICODEMO, 2001). Vários estudos que abordam essa questão da susceptibilidade a antimicrobianos de patógenos da mastite bovina no Brasil (QUEIROZ et al., 2004), revelaram um aumento crescente no padrão de resistência, principalmente em relação ao Staphylococcus aureus.

De acordo com Pinto (2000), o tratamento com medicamentos ideal para mastite seria aquele que pudesse controlar todos os processos infecciosos do úbere e ainda não deixasse resíduos no leite. O primeiro relato observado na 
literatura sobre a utilização de um protocolo de tratamento de mastite através da própolis remonta da década de 80 (MIROLYUBOV e BARSKOV, 1980).

Segundo Valero (2010), em estudo avaliando o desempenho de bovinos mestiços terminados em confinamento alimentados com dieta controle e com adição de monensina e própolis observou que o ganho médio diário, conversão alimentar, peso final o peso da carcaça quente e rendimento da carcaça, mostraram-se semelhantes para bovinos alimentados com dietas controle, e com aditivos (monensina sódica e produtos a base de própolis) como demostrado na Tabela 10.

Tabela 10: Desempenho de bovinos mestiços terminados em confinamento

\begin{tabular}{lccc}
\hline Parâmetros & \multicolumn{3}{c}{ Dietas $^{1}$} \\
\cline { 2 - 4 } & CON & MON & PRO \\
\hline $\mathrm{N}$ & 14 & 11 & 13 \\
\hline Peso inicial, $\mathrm{kg}$ & $393,29+8.20$ & $395,73+9,25$ & $395,46+8,50$ \\
Peso final, kg & $494,86+9,15$ & $504,18+10,32$ & $505,23+9,49$ \\
Ganho médio diário, $\mathrm{kg}$ & $1,45+0,07$ & $1,55+0,08$ & $1,57+0.08$ \\
Conversão alimentar & $8,67+0,48$ & $7,43+0,55$ & $8,07+0,50$ \\
Peso de carcaça quente, kg & $246,91+5,38$ & $251,90+5,71$ & $254,97+5,46$ \\
Rendimento de carcaça\% & $49,90+0,57$ & $49,98+0,57$ & $49,98+0,40$ \\
\hline 1 Rações com 50:50\% volumoso: concentrado sem aditivo(CON) e com adição de monensina \\
sódica (MON) ou produtos a base de própolis (PRO). Adaptado de Valero (2010).
\end{tabular}

Para o gado de leite e novilhas a dosagem de aditivo a base de própolis para atuar na eficiência alimentar e para aumentar a produção de leite varia entre 10 a $20 \mathrm{~g} /$ cabeça/dia (STRADIOTTI JR et al., 2004).

A utilização de própolis, levedura e outros aditivos naturais na dieta animal propicia uma redução da concentração de amônia ruminal, e apresenta uma ação estimulante sobre determinados microrganismos ruminais o que favorece o aumento de sua população, e consequentemente ocorrendo uma maior incorporação da amônia na proteína microbiana, justificando a redução na concentração de amônia no rúmen. Segundo a literatura, o aumento na síntese de proteína no rúmen pode ser fundamental para suprir as necessidades de aminoácidos específicos para animais em crescimento ou de 
alta produção, seja na produção da carne, bem como na produção de leite (OLIVEIRA et al., 2004).

\section{CONSIDERAÇÕES FINAIS}

Algumas considerações podem ser realizadas com relação à própolis na dieta nutricional dos ruminantes, como redução da produção de amônia decorrentes das fontes de proteína de maior degradabilidade.

A utilização da própolis pode ser mais eficiente que a monensina no que se refere a reduzir maiores concentrações de proteína solúvel, pela redução da atividade de deaminação, tanto in vitro quanto in vivo.

A própolis favorece o aumento da concentração total de ácidos graxos voláteis, o que propicia aos ruminantes, maior possibilidade de atender as exigências nutricionais de mantença e ganho.

O uso dos aditivos naturais, tais como a levedura e a própolis, melhoram substancialmente a eficiência e a qualidade do produto animal. Ocorre um ganho por kg de proteína ingerida e as adições de própolis (produto natural) sem dúvidas pode ser um substituto da monensina sódica que está proibida em alguns países, principalmente na comunidade europeia.

\section{REFERÊNCIAS}

ADELMANN, J. Própolis: variabilidade composicional, correlação com a flora e bioatividade antimicrobiana / antioxidante. 2005. 186 p. Dissertação (Mestrado em Ciências Farmacêuticas), Setor Ciências da Saúde, Universidade Federal do Paraná, Curitiba, 2005.

AGUIAR, S. C. Produtos a base de própolis (LLOS) na dieta de bovinos mestiços não castrados em confinamento. 2009. 58 p. Dissertação (Mestrado em Zootecnia), Concentração de Produção Animal, Universidade estadual de Maringá, Maringá, 2009.

BERCHIELLI, T , T, PIRES , A.V , OLIVEIRA,S.G. Nutrição de ruminantes.Jabuticabal. Funep, 2006. 583p.

CABRAL, I. S. R. Isolamento e identificação de compostos com atividade antibacteriana da própolis vermelha brasileira. 2008. 95 p. Dissertação (Mestrado em Ciência e Tecnologia de Alimento), Escola Superior de Agricultura Luiz de Queiroz, Universidade de São Paulo, Piracicaba, 2008. 
CASIMIRO, T. R. Produtos a base de Própolis para bezerras lactentes. 2008. $49 \mathrm{p}$. Dissertação (Mestrado em Zootecnia), Área de Concentração de Produção Animal, Universidade Estadual de Maringá, Maringá, 2008

FARNESI, A. P. Efeitos da Própolis de abelhas africanizadas e meliponíeos em microorganismos. 2007. 89 p. Dissertação (Mestrado em Ciência), Área de Concentração Genética, Universidade de São Paulo, Ribeirão Preto,2007.

FILHO, S. C. V. Fermentação Ruminal: Nutrição de Ruminantes. Jaboticabal: FUNEP, 2006. p. $151-182$

FREITAS. J. A. et al. Extrato etanóico de própolis na alimentação de vacas leiteiras .Revista Brasileira Saúde e Produção Animal, Palotina, v. 10, n. 2, p. 333-343, abr/jun. 2009.

GONSALVES N. J.; PEDREIRA, M. S. Uso da própolis na nutrição de ruminantes. PUBVET, Londrina, v. 4, n. 5, ed. 110, art. 740. 2010.

GOULART, T. C. S. Estudos preliminares sobre atividade "in vitro" do extrato etanólico de própolis (EEP) no combate de bactérias isoladas de processos infecciosos de animais. 1995. 57 p. Monografia (Graduação em Zootecnia), Universidade Federal da Bahia, Salvador, 1995.

LOUREIRO, C. M. B. Redução de verminose, parâmetros hematológicos e bioquímicos de cordeiros alimentados com extrato de própolis na ração. 2007. 54 p. Dissertação (Mestrado em Zootecnia), Produção Animal, Universidade Estadual Paulista Júlio de Mesquita Filho, Jaboticabal, 2007.

MARTINS, A. S. et al. Consumo e digestibilidade aparente total em bovinos sob suplementação com enzimas fibrolíticas. Revista Brasileira de Zootecnia v. 35, n. 5, p. 2118-2124, 2006.

NICODEMO, M. L. F. Uso de Aditivos na dieta de Bovinos de Corte. Comunicado Técnico EMBRAPA, Campo Grande, out. 2001

OLIVEIRA, J. O. et al. Efeito da monensina e da própolis sobre a produção de amônia e degradabilidade In vitro da proteína bruta de diferentes fontes de nitrogênio. Revista Brasileira de Zootecnia, v. 33, n. 2, p. 504-510, 2004.

OLIVEIRA, R. R. et al. Efeito da adição de própolis ao meio diluidor e suas influências nas características físicas do sêmen equino resfriado a $5^{\circ} \mathrm{C}$ e $15^{\circ} \mathrm{C}$. In: SIMPÓSIO DE INICIAÇÃO CIENTÍFICA, 18, 2007, Viçosa. Anais... Viçosa: Universidade Federal de Viçosa, 2007.

OLIVEIRA, J.S. et al . Efeito da monensina e da própolis sobre a atividade de fermentação de aminoácidos in vitro pelos microrganismos ruminais. Revista Brasileira de Zootecnia, v. 35, n. 1 , p. $275-281,2006$.

PARK,Y.K ; IKEGAKI ; ALENCAR, S.M. Classificação da própolis brasileira a partir de suas caracteríticas fiscoquímicas e propriedades biológicas. Mesagem Doce, v.58,2000.Disponível em : <http://www.apacame.org.br/mensagemdoce/58/artigo.htm>.Acessado em:14 de abril de 2012.

PEREIRA, A. S.; SEIXAS, F. R. M. S.; NETO, F. R. A. Própolis: 100 anos de pesquisa e suas perspectivas futuras. Química Nova, v. 25, p. 321-326, 2002. 
PINHEIRO, M. S. Avaliação da atividade antimicrobiana e citoprotetora gástrica dos extratos de mangaba, caju e própolis vermelha. 2009. 69 p. Dissertação (Mestrado em Saúde e Ambiente), Universidade Tiradentes, Aracajú, 2009.

PINTO, M. S. Efeito antimicrobiano de própolis verde do Estado de Minas Gerais sobre bactérias isoladas do leite de vacas com mastite. 2000. 104 p. Tese (Magister Scientiae), Universidade Federal de Viçosa, Viçosa, 2000.

PRADO, O. P. P. et al. Digestibilidade e parâmetros ruminais de dietas a base de forragem como adição de própolis e monensina sódica para bovinos. Revista Brasileira de Zootecnia, Viçosa, v. 39, n. 6, p. 136-1345, 2010.

PRADO, O. P. P. Produto à base de própolis na nutrição de ruminantes (LLOS). 2005. 107 p. Dissertação (Mestrado em Produção Animal), Universidade Estadual de Maringá, Maringá, 2005.

PRADO, O. P. P. Própolis e monensina sódica em dietas volumosas sobre a digestibilidade e características ruminais de bovídeos. 2001. $111 \mathrm{p}$. Tese (Doutorado em Produção Animal), Área de concentração Produção Animal, Universidade Estadual de Maringá, Maringá. 2008.

QUEIROZ, R. C. et al . Uso de produto à base de enzima e levedura na dieta de bovinos: digestibilidade dos nutrientes e desempenho em confinamento. Revista Brasileira Zootecnia, Viçosa, v. 33, n. 6, p. 1548-1556 2004.

RIGHI, A. A. Perfil químico de amostras de própolis brasileiras. 2008. 102 p. Dissertação (Mestrado em Ciência Botânica), Instituto de Biociências, Universidade de São Paulo, São Paulo, 2008.

RÍSPOLI, T. B. et al. Protozoários ciliados do rúmen de bovinos e bubalinos alimentados com dietas suplementadas com monensina ou própolis. Pesquisa Agropecuária Brasileira, Juiz de Fora, v. 44, n. 1, p. 92-97, jan. 2009.

RIVERA, N. L. M. Extrato de própolis na alimentação de cães. 2001. 95 p. Tese (Doutorado em Zootecnia), Área de Concentração de Produção Animal, Universidade Estadual de Maringá, Maringá, 2011.

SANTOS, J. E. P.; SANTOS, F. A. P. Monitoramento do manejo nutricional em rebanhos leiteiros: produção animal na visão dos brasileiros. Piracicaba: FEALQ, 2001927 p.

STRADIOTTI Jr., D.; QUEIROZ, A.C.; LANA, R.P. et al. Ação da própolis sobre microrganismos ruminais e sobre alguns parâmetros de fermentação no rúmen. In: REUNIÃO ANUAL DA SOCIEDADE BRASILEIRA DE ZOOTECNIA, 38.2001, Piracicaba. Anais... Piracicaba: Sociedade Brasileira de Zootecnia. Julho, 2001. p.942-944

STRADIOTTI JR., D. et al. Ação da própolis sobre a fermentação in vitro de diferentes alimentos pela técnica de produção de gases. Revista Brasileira de Zootecnia, v. 33, n. 4, p.1093-1099, 2004.

STRADIOTTI JR, D. et al.Ação da própolis sobre a desaminação de aminoácidos e a fermentação ruminal. Revista Brasileira de Zootecnia, v. 33, n. 4, p. 1086-1092, 2004.

SIMIONI, F. L. Própolis como aditivo alimentar para bovinos de corte. 2011. 91 p. Tese (Doutorado em Zootecnia), Área de Concentração de Produção Animal, Universidade Estadual de Maringá, Maringá, 2011. 
SILVA, J. F. C, LEÃO, M. I Fundamentos de nutrição de ruminantes. Piracicaba.Livroceres, 1979 487p.

VALERO, M. V. Monensina ou própolis na dieta de bovinos mestiços terminados em confinamento: desempenho, digestibilidade, produção microbiana, características de carcaça e do músculo longissimus. 2010. 77p. Dissertação (Mestrado em Zootecnia), Área de Concentração de Produção Animal, Universidade Estadual de Maringá, Maringá, 2010. 